\title{
膀朕移行上皮癌の治療成績
}

$\begin{array}{ccccc} & \text { 本 } & \text { 間 } & \text { 之 } & \text { 夫 }^{1)} \\ & \text { 杉 } & \text { 山 } & \text { 義 } & \text { 樹 } \\ \text { 三井記念病院泌尿器科 } & \text { 北 } & \text { 村 } & \text { 唯 } & \text { 一 } \\ & \text { 中 } & \text { 村 } & \text { 昌 } & \text { 平 } \\ & \text { 西 } & \text { 村 } & \text { 洋 } & \text { 司 }\end{array}$

\section{CLINICAL STUDY ON TRANSITIONAL CELL CARCINOMA OF THE BLADDER}

\author{
Yukio Honma, Yoshiki Sugiyama, Tadaichi Kitamura, Shohei Nakamura and \\ Yoji Nishimura \\ Urology Division, Mistui Memorial Hospital
}

\begin{abstract}
Consecutive 128 cases of transitional cell carcinoma of the urinary bladder were analyzed related to pathological findings and the mode of operation: transurethral resection or partial cystectomy (conservative operation) and total cystectomy. Indication of operation was determined mainly by cystoscopic findings. In 83 cases for coservative operation, no cancer death was found and only one was finally cystectomized. In 45 cases for total cystectomy, a good five-year survival rate of $58 \%$ was obtained, although 2 cases seemed to be treatable by conservative operations.

These results show that indication of conservative operation is successfully determined by cystoscopic findings and rarely forced to be changed even for recurrent tumors, and total cystectomy should be carefully indicated by utilizing diagnostic tools other than cystoscopy.
\end{abstract}

\footnotetext{
要旨：過去 12 年 5 カ月の 128 例の膀胱移行上皮癌について, その治療成績を, 病理所見と手術方法に対比 して検討した. 当科では, 膀胼鏡所見で適応を決め, 経尿道的手術か膀胱部分切除術(膀胱保存術)，む しくは膀胱全摘除術を行なってきた。 その結果, 膀胱保存術を受けた83例中には, 癌死をたは腫瘍が進 展し根治術不能となった例はなく，最終的に全摘術となった例も1例のみで, 手術適応はほぼ正しかっ た。全摘術を受けた 45 例では，5年生存率は $58 \%$ と良好であったが, 結果的にみて, 膀脱保存術でも治 療できたと思われる症例が 2 例あった。

以上の結果から，膀胱保存術適応の判断は膀胱鏡所見でほほ十分で，再発をくり返しても，大部分は 膀胱保存的に治療可能なこと, 全摘術の適応の判断には, 膀胱鏡所見以外の補助診断法で慎重に検討す べきことが示された。
}

\section{緒}

昭和 45 年 4 月, 当院は三井厚生病院より三井記念病 院と改名し, 設備, 人員とも払充した。 以来, 昭和 57 年 8 月までの 12 年 5 カ月間に 171 例の膀脱腫瘍を治療 した。そのうち, 手術的治療を受けた移行上皮癌 128 例 の成績を総め, 特にその手術適応の適否について考察 したので，ここに報告する.

1）現在 東大病院泌尿器科

\section{方 法}

対象患者：昭和 45 年 4 月 1 日より，昭和 57 年 8 月 30 日までの 12 年 5 カ月間に, 当科で治療を開始した膀胱 腫瘍患者は171例であった。このうち，今回の検討で 扱ったのは, 初回治療上り連続して当科で根治目的に 手術を行い, 58 年 1 月現在で予後が確認され，死亡例 を除いては, 術後観察期間が 6 カ月以上ある, 膀胼原 発の移行上皮癌128例に限った. 従って, 6 カ月以上の 予後検索不能の 5 例, 過去もしくは経過中他院で治療 された 22 例，根治的治療を行いえず死亡した 1 例，放 
射線治療のみ行なった 1 例，尿膜管腫瘍 3 例，腎孟尿 管腫瘍に続発, 併発した膀胱腫瘍 9 例, 膀脱肉腫 1 例, 膀胼原発の扁平上皮癌 1 例は, 本検討より除外した。

対象患者の年齢は, $28 \sim 85$ 歳, 平均61.1歳で，男 97 人女 31 人, 死亡例も含め観察期間は 1 力月 12 年 6 力 月, 平均 4 年 4 カ月であった.

手術の適応とその方法：当科では, 下記の如く適応 を決め手術を行なってきた。

(1) TUR 膀胱鏡所見上，乳頭状，または非乳頭状で も茎が明らかで，その周囲には浮腫，充血がなく，か つほぼ全景が確認され切除可能と判断されるもの. 但 し, 茎が太く, 腫瘍近傍の粘膜が浮腫状となっていて も，母指頭大までのものならば，積極的に excision biopsy としてTURを行い, 術後病理所見で再検討し た。方法は通常行なわれているものと大差ないと思わ れる. 腫瘍以外の粘膜の生検は, 通常行なわなかった。 術後の膀腅内注入療法は, 主に多発性で頻回に再発す る腫瘍に行なって扣り，抗癌剂の種類，投与方法も一 定ではなかった。術後は， 1 年以内は 3 カ月ごと，以 降は 6 カ月から 1 年毎に膀胱鏡検査を行なった.

(3) 膀脱部分切除術 膀胱㮩室内のもの.膀胱鏡所見 上, 単発腫瘍で, 肉眼的に他の粘膜には腫瘍, ビロー ド状変化, 発赤, 浮腫などが認められないもの。この 場合, 腫瘍が非乳頭状で, 茎が太く, 漫潤性腫瘍の疑 いがあっても，母指頭大以下ならば適応とした，方法 は, 腫演より通常 $3 \mathrm{~cm}$ 位 ${ }^{11)}$, 少なくとも $1.5 \mathrm{~cm}$ 以上 ${ }^{27)}$ 離して切除した。病理所見上, 腫瘍のとり残しが疑わ れる場合は, 抗癌剂の膀胱内注入か, ${ }^{60} \mathrm{Co}$ の膀脱放射 線照射を行なった。術後の follow up は TUR と同様 の形式であった。

(3) 膀羘全摘除術 膀胱鏡所見上, TUR もしくは部 分切除では, 根治困難と判断したもの.つまり, 大き く全景が明らかでないもの，母指頭大以上の大きさが あり, 非乳頭状, 広基性で, 腫瘍周囲の粘膜が浮腫状 となり，深部浸潤癌の可能性があるもの．たとえ小さ くとも, 同様の所見で浸潤癌が疑われ, 他の粘膜に, 腫瘍, ビロード状変化, 浮腫などの変化を認めるもの. excision biopsyとして行なった TUR 標本の病理所 見上, stage が $\mathrm{pT}_{2}$ 以上で, 腫瘍残存の可能性の高いも のなどである.

方法は, 原則として, 男子では, 膀胱, 前立腺, 精 囊, 尿道全長を一塊として摘出, 女子では, 膀胼, 尿 道全長, 子宮, 腔前側壁を一塊として摘出した。リン 八゚節郭清も, 原則として行い, 大動脈分岐直上から両
側外腸骨動脈の遠位端までの総腸骨，外腸骨リンパ節 と, 内腸骨リンパ節，閉鎖リンパ節について行なった。 術後の治療は, 手術所見之病理所見を検討し, 腫瘍が

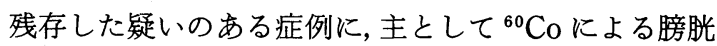
部への放射線照射を行なった，尿路変更は，通常一期 的に行い，尿管 S 状結腸吻合術 (Goodwin の変法によ $る^{5)}$ ) もしくは, high risk や根治性の期待できない症 例には，尿管皮膚瘻術を行なった。

対象症例は, 上記 3 種類の手術のいずれかで治療さ れたが, 便宜上, 以下の 3 群の手術群に分類した。

(1) TUR 群 TURのみで治療された症例

(2) 部分切除群 膀胱部分切除術を受けた症例. 前後 にTURで治療された症例も含めた。

(3) 全摘群 膀脱全摘除術か骨盤内臓器全摘除術を 受けた症例. 以前に膀胱保存術を受けていても最終的 に全摘術となった場合は, この群に含めた。

腫瘍の病理分類：病理所見の分類は, 膀胱癌取扱い 規約に従って行なった ${ }^{18)}$. 症例数が十分でないため, grade $0,1,2$ low grade, grade 3 high grade と 2 分し, stage についても, $\mathrm{pTa}, \mathrm{pT}_{1}$ を low stage, $\mathrm{pT}_{2}$ 以上を high stage と 2 分した. 同一膀胱に grade, stage の異なる腫瘍がある場合は, 高い方を適用した。 TUR で得た標本には, stage 判定の困難なものもあっ たが，調べられた範囲で stage をつけた。

生存率と再発率の算定: 生存率は, TUR 群では初 回の TUR から, 部分切除群, 全摘群では, 各々部分切 除術, 全摘術を受けた時より起算した実測生存率を示 した. 再発率は, 非再発率を生存率と同様に算出し, 1 から減じて示した。

\section{結 果}

各手術群の症例数は, 表 $1,2,3,4$ 亿腫瘍の病 理所見とあわせて示した. TUR 群の病理所見は, 初発 腫瘍を基準とした. grade, stage の不明の 3 例はいず れも腫瘍が小さく焼灼してしまい, 標本のとれなかっ た例である。

生存率については, 表 5 に実測 5 年生存率を, 手術 群別, grade 別, stage 別に一覧表とした. 経時的变化 は, 図 1, 2a,b, 3a,bに示した. 図 1 には, 手術群別に 示した. 図2a,bには TUR 群と部分切除群の80例につ いて, 図3a,bには全摘群の45例について, grade 別, stage 別に示した.

再発率に関しては, 因 4 に治療法別に, 図 5 には TUR 群70例で, 膀胖内注入療法の有無別に示した。

以下に, 各手術群について述べる. 
表 1 全症例の grade 別 stage 別症例数

\begin{tabular}{|c|c|c|c|c|c|}
\hline & \multicolumn{3}{|c|}{ Grade } & \multirow{2}{*}{ 計 } \\
\hline & & Low & High & 不 明 & \\
\hline \multirow{3}{*}{ 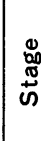 } & Low & 75 & 14 & & 89 \\
\hline & High & 9 & 27 & & 36 \\
\hline & 不 明 & & & 3 & 3 \\
\hline \multicolumn{2}{|r|}{ 計 } & 84 & 41 & 3 & 128 \\
\hline
\end{tabular}

表 2 TUR 群の grade 別 stage 別症例数

\begin{tabular}{|c|c|c|c|c|c|}
\hline & \multicolumn{3}{|c|}{ Grade } & \multirow{2}{*}{ 計 } \\
\hline & & Low & High & 不 明 & \\
\hline \multirow{3}{*}{ 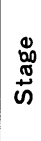 } & Low & 59 & 6 & & 65 \\
\hline & High & & 2 & & 2 \\
\hline & 不 明 & & & 3 & 3 \\
\hline \multicolumn{2}{|r|}{ 計 } & 59 & 8 & 3 & 70 \\
\hline
\end{tabular}

表 3 部分切除群の grade 別 stage 別症例数

\begin{tabular}{|c|c|c|c|c|}
\hline & \multicolumn{2}{|c|}{ Grade } & \multirow{2}{*}{ 計 } \\
\hline & & Low & High & \\
\hline \multirow{2}{*}{$\begin{array}{c}0 \\
\underset{0}{\pi} \\
\stackrel{0}{0}\end{array}$} & Low & 6 & 1 & 7 \\
\hline & High & 2 & 4 & 6 \\
\hline \multicolumn{2}{|r|}{ 計 } & 8 & 5 & 13 \\
\hline
\end{tabular}

表 4 全摘群の grade 別 stage 別症例数

\begin{tabular}{|c|c|c|c|c|}
\hline & & \multicolumn{2}{|c|}{ Grade } & \multirow{2}{*}{ 計 } \\
\hline & & Low & High & \\
\hline \multirow{6}{*}{ 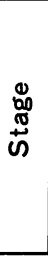 } & Low & 10 & 7 & 17 \\
\hline & High & 7 & 21 & 28 \\
\hline & $\mathrm{pT}_{2}$ & 6 & 7 & 13 \\
\hline & $\mathrm{pT}_{3} \mathrm{a}$ & & 1 & 1 \\
\hline & $\mathrm{pT}_{3} \mathrm{~b}$ & 1 & I I & 12 \\
\hline & $\mathrm{pT}_{4}$ & & 2 & 2 \\
\hline \multicolumn{2}{|c|}{ 計 } & 17 & 28 & 45 \\
\hline
\end{tabular}

(1) TUR 群 表 1 に示すように症例は70例あった。 死亡は 4 例であるが，全例他因死であった。

病理所見別に経過を検討すると, low grade, low stage は59例であり，30例で 1 １0回再発したが，いず れも low grade, low stageであった。
表 5 手術群別 grade 別 stage 別の実測 5 年生存率

\begin{tabular}{|c|c|c|c|c|c|c|c|}
\hline \multirow{2}{*}{ 手術方法 } & \multirow{2}{*}{ 全例 } & \multicolumn{3}{|c|}{ Grade } & \multicolumn{3}{|c|}{ Stage } \\
\hline & & Low & High & 不明 & Low & High & 不明 \\
\hline 膀胱保存術 & 90.5 & 88.7 & 100 & 100 & 89.4 & 100 & 100 \\
\hline TUR & 91.5 & 90.1 & 100 & 100 & 90.5 & 100 & 100 \\
\hline 部分切除術 & 84.6 & 77.8 & 100 & & 77.8 & 100 & \\
\hline 膀胱全摘術 & 57.5 & 73.4 & 47.6 & & 76.0 & 45.3 & \\
\hline 例 & 78.5 & 86.0 & 61.9 & 100 & 86.9 & 55.2 & 100 \\
\hline
\end{tabular}

因 1 手術群別. 実測生存率

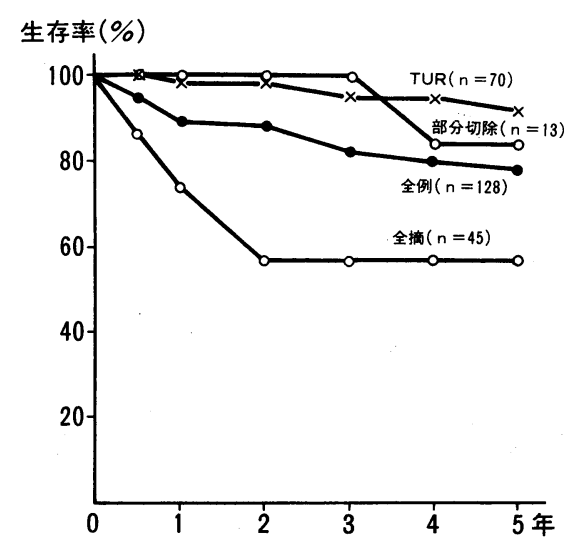

high grade, low stage の腫瘍の 6 症例については, その stage は pTa が 1 例, $\mathrm{pT}_{1}$ が 5 例で, 全例術後に 抗癌剤の膀胱内注入を受けたが，4 例で再発した、ら ち, high stage に進行した 2 例について詳述すると, 第 1 例めは, 63歳男で, 初発腫瘍は grade $3, \mathrm{pT}_{1}$ で, 2 年 7 力月後異所性に再発し grade $3, \mathrm{pT}_{2}$ 更に 6 力 月後同所に再発し grade $3, \mathrm{pT}_{1}$ であった. TUR では 根治不能の可能性があるが, 肝障害のため通院不能と なった。術後 2 年経過したが, 肝障害で他院入院中で 当科に受診不能である。第 2 例目は, 76 歳男で, 初発 腫瘍は grade $3, \mathrm{pT}_{1}$ であった. 7 力月後, ほぼ同所に 再発し, grade $3, \mathrm{pT}_{3} \mathrm{a}$ 以上で, 他の粘膜に生検で上 皮内癌を認めた．全摘術の適応と考学るも，全身状態 不良のため放射線照射の夕行い，2 カ月経過観察中で ある。

high grade, high stage 22 症例は, いずれも単発 腫瘍で, 病理所見は grade $3, \mathrm{pT}_{2}$ であった。術後抗癌 剂の膀脱内注入を行い, 4 力月後と50力月後の膀胱鏡 では再発を認めていない。

(2) 部分切除群 表 3 に示すように症例は13例あっ 
図 2 TUR 群と部分切除群の grade 別 (a ) stage 別

(b) 実測生存率

a

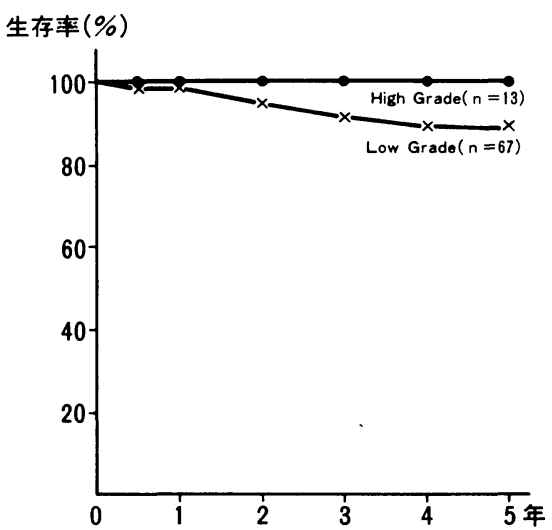

b

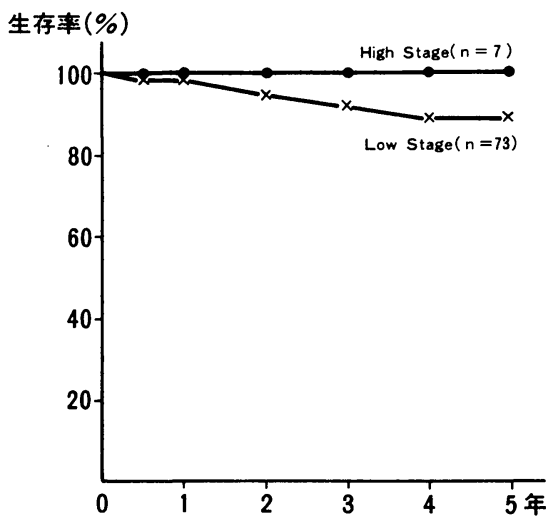

た. $5 ち$ 死亡が 2 例あったが，ともに他因死であった。 腫瘍が尿管口に近く，尿管膀脱新吻合術もあわせて行 なった例は 5 例あった。

病理所見別に経過をみると, low grade, low stage は6 例で, $5 ち 3$ 例で 1 回再発した。 2 例は, 再発腫 瘍も low grade, low stage で，TUR で治療された。 残る 1 例は, 初発腫瘍は, 右壁の膀腅憩室内と, 後壁 の右寄りの 2 力所にあった。多発腫瘍ではあったが, 主腫瘍は賏室内で，娘腫瘍も併せて切除できると判断 し, 部分切除術を行なった. 病理所見は, grade $2, \mathrm{pT}_{1}$ であった. 然し， 2 年後に多発性に再発し, TURを受 け, grade 3, pTaであったので, 術後4,000rads の放 射線照射を受けた。厳重に経過観察を行なったが，1 年後心筋梗塞で死亡したため，腫瘍に関しては検討不 十分となってしまった。
図 3 全摘群の grade 別 (a) stage 別 (b) 実測生存 率

a

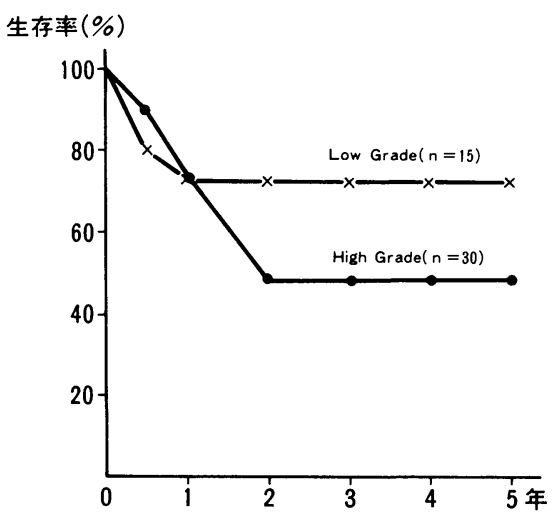

b

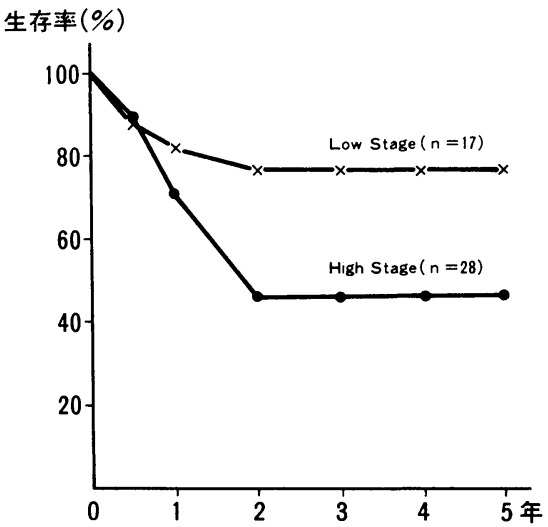

high grade, low stage の 1 例は, 術後5,000rads の 放射線照射を受け再発もなかったが， 6 年後に放射線 性膀胀炎のため，膀胼摘出を余儀なくされた。

high stage の症例は 6 例で, low grade 2 例, high grade 4 例であった. low gradeの 2 例は, ともに grade $2, \mathrm{pT}_{2}$ で, high grade の 4 例は, grade は 3 で, stage は $\mathrm{pT}_{2} 1$ 例, $\mathrm{pT}_{3} \mathrm{a} 1$ 例, $\mathrm{pT}_{3} \mathrm{~b} 2$ 例であった. 術後 $\mathrm{pT}_{3} \mathrm{a}$ の例は膀脱内注入療法, $\mathrm{pT}_{3} \mathrm{~b}$ の例は放射線 照射を受けた。これら high stage の 6 例の予後は良好 で, 術後 8 - 41力月, 平均 25 力月後までの膀脱鏡検査 で，全く再発を認めなかった。

(3) 全摘群 表 4 に示すように症例は45例であった。 らち死亡が20例あった。死因は, 癌死14例, 合併症死 3 例, 他因死 3 例であった. 合併症死の 3 例は昭和 46 , 49, 53年の各 1 例で, ともに腸閉塞, 腹膜炎による死 
図 4 TUR 群と部分切除群の再発率

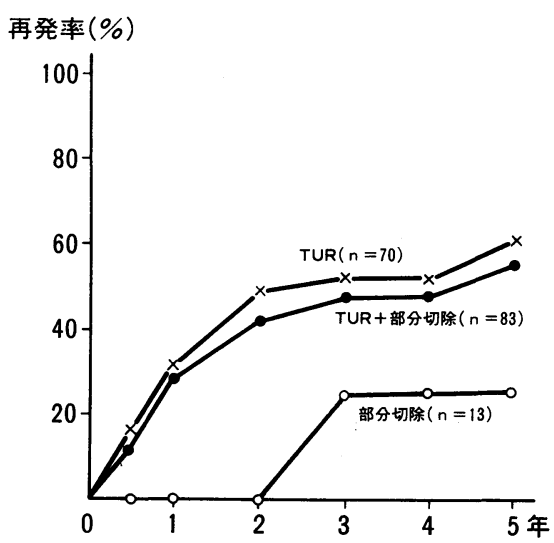

図 5 TUR 群で抗癌剤膀脱内注入有無別にみた再発 率

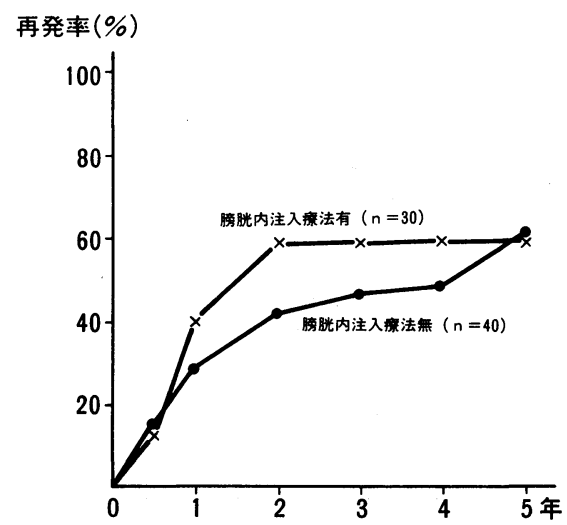

亡であった.リンパ節郭清は39例で行い， 6 例に 1 か ら32個の転移を認め，らち5 例は死亡した。残る 1 例 は生存中だが, 局所再発があった。

病理所見別には, high grade または high stage で生 存率は明らかに不良であった. high stage 中でも, $\mathrm{pT}_{2}$ の 13 例では癌死は 3 例にすぎないが, $\mathrm{pT}_{3} \mathrm{a}$ 以上の 15 例では, 11例が癌死もしくは生存中でも残存腫瘍が あった。

病理所見から全摘術適応の適否を検討すると, high grade, high stage 以外の症例でも, 腫瘍が非常に大き いか, 浸潤癌か, 多発癌か粘膜に上皮内癌や異型上皮 を伴うなどで，大部分の例では，膀胱保存術では根治 困難と考えられた. 然し, low grade, low stage の10 例のうち 1 例は, 主腫瘍は $4 \times 3.5 \times 2.5 \mathrm{~cm}$ で数コの 娘腫瘍があったが, 病理所見はすべて grade 1, pTa で
あった. また, high grade, low stage の 7 例のらち 1 例は, 単発腫痬で $3.2 \times 3.2 \times 1.1 \mathrm{~cm}$ の大きさで, 他の 粘膜には前癌状態を疑わせる所見はなく, 腫瘍の病理 所見は, grade $2>3, \mathrm{pT} \mathrm{T}_{1} \mathrm{a}$ であった。これら 2 例は, 膀胱鏡検査で腫瘍の大きさを過大評価された例で，結 果的には, 膀胼保存例でも治療が可能であったかと思 われた。

全摘群45例のうち, 術前に膀胼保存術を受けていた

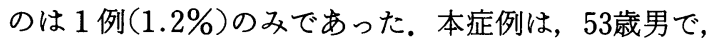
初回に部分切除を受け grade $2, \mathrm{p} \mathrm{T}_{1}$ であった。 その後 1 年間に 2 回再発したが, 腫瘍は多発性ながら $1 \mathrm{~cm}$ 未 満の乳頭状の小腫瘍であった，TUCで治療したため 病理所見は不明だが，肉眼的所見からみて，明らかな 病勢の進行は認められなかった，次いでその 4 力月後 再発し，その際超音波検査などで浸潤が疑われ，全摘 術を行なった。摘出標本はgrade $2, \mathrm{pT}_{1}$ であったが, 全摘術の適応でもあったと思われる。

\section{考察}

TURの適応は正しかったか.

TUR で治療された症例の 5 年生存率（粗または実 測生存率)は，47.5 92.7\% と報告1214)6)7)10113)19)21)32)さ れている. また, 初回治療より TURで治療されていて 全摘術となった症例の頻度については, $2.3 \sim 5.4 \%$ と 報告されている8)13)24)28).

当科では，TUR 群の 5 年実測生存率は $91.5 \%$ と良 好であった。 また, TUR 後全摘術をらけたのは84例中 1 例 (1.2\%) で, 結果(3)で述べた通り, その症例も絶 対的適応とはいい難かった. 更に, 本例を含めて, TUR で治療されていて癌死となったり，腫瘍が進展し根治 的治療困難となった例もなかった。この中には, high gradeまたは high stageの腫瘍を根治しえたと思わ れる例もあり, TURの高い根治性を裏づけると思わ れた ${ }^{1) 8)}$. 然し, high grade, low stage の 6 例の ちちに, high stage に進行した例が 2 例あり, high grade の腫 瘍は，特に厳重な観察が必要と考えた。

以上より，TURの適応はほぼ正しかったが，high grade の腫瘍では厳重な経過観察が必要と思われた。

な拈，膀脱内注入療法の再発予防効果については， 少なくとも今回の検討では効果を認めなかった。 しか し, 注入療法の適応, 方法が無作為でなく, 評価不能 と思われた。

部分切除術の適応は正しかったか.

部分切除術で治療された症例の 5 年生存率は 20.0〜 75.0\%と報告4)8)9) 12)15)19)21)27)29)32)されている. 
当科では 5 年実測生存率 $84.6 \%$ と良好で, 癌死もなく, ほぼ正しい適応であったと思われる。

ところで，膀胼部分切除術については，その適応の みならず, 存在そのものについても議論がある。つま り，根治性の高い手術として評価する者のある一 方 ${ }^{1215) 27)}$ ，適応例はわずかであるとする者から ${ }^{20)}$, 根治 例としてTUR か全摘術しか認めていない施設13) で ある。

当科の症例を検討すると, 再発は13例中 3 例のみで, high stage の 6 例についても, 根治的治療をなしえた と思われた。この high stage の腫瘍の少なくとも一部 のものは, 全摘標本の検索の結果指摘された ${ }^{16225)}$. 局所 的で浸潤性の腫瘍にあたると思われる.その治療には, 小さい腫瘍ならば，TURでは困難であっても全摘術 の必要はなく, 部分切除術でよいであろら。一方, 多 発腫瘍に対して部分切除術を施行した例では, 術後経 過は必ずしも良好ではなかった。従って, 当科の少数 ながら13例の経験から考光, 単発の high stage の腫湯 や膀腅馣室内腫瘍の中には, TUR では根治困難でも 部分切除術で根治できる症例があると思われた。

全摘術の適応は正しかったか.

全摘術の適応規準は，浸潤性腫瘍か非浸潤性腫瘍で も多発し膀胱保存術困難な場合とするのが一般的であ ろら.全摘術をらけた症例の予後については, 5 年生存 率で0 76.0\%と報告され， high gradeはlow gradeに 比べ, high stageはlow stageに比べ, 明らかに予後 不良と言われている(2) 4)8) 10)13)19)21) 23)26(28)30) 32). 手術死亡率については，1.17～14\%と報告されてい $ろ^{3(13) 22(24) 26) 30311}$.

当科の検討結果では， 5 年生存率は $57.5 \%$, 術後の 合併症死は $6.7 \%$ とこれらの報告と同様であり,手術適 応, 方法には大過はなかったものと考兄られる. 然し, 結果(3)で述べたよ5に, 膀胱保存術でも治療可能で あったかと思われる症例が 2 例あった。こうした症例 を検出するには，膀胱鏡所見だけでは不十分で，膀胱 二重造影 ${ }^{14)}$, 経尿道的超音波診断法 ${ }^{17)}, \mathrm{CT}^{7)}$ などの補助 診断法を活用し，慎重に適応を決定する必要があると 思われる。

\section{今後の膀脂腫瘍の手術適応について}

以上の考察の通り, 今後も「方法」の項で述べたよ らな根拠で手術適応を決めて, 大過ないものと考える. これからの展望としては, 以下の 4 点を考えている.

1） high grade の腫瘍を TUR で治療した場合, 今ま でにも増して厳重に経過観察をする。
2）膀胱部分切除術の適応と思われる症例には, 腫瘍 以外の生検をあわせて行なら。

3）全摘術の適応は, 膀胼鏡以外の補助診断法を活用 し，慎重に検討する.

4）手術適応の最大根拠が，膀胱鏡所見である. ことは, くり返し述べた。しかし, 残念なことに, 膀 胱鏡所見の統一した書式や評価体系がない. 今後は, その書式や体系に更に検討を加光る予定である.

\section{結 語}

過去 12 年 5 カ月の間に治療した 128 例の膀羘移行上 皮癌の手術適応とその成績を検討し, 今後の治療指針 の一助とした。

病理学的検索について, 終始御援助, 御指導下さった当院 病理科高梨利一郎部長に深謝致します。

\section{文献}

1) Narnes, R.W., Dick, A.L., Hadley, H.L. and Johnston, O.L. : Survival following transurethral resection of bladder carcinoma. Cancer Res., 37, 2895-2897, 1977.

2) Bowles, W.T. and Silber, I. : Carcinoma of the bladder: A computer analysis of 516 patients. J. Urol., 107, 245-247, 1972.

3) Bracken, R.B., McDonald, M.W. and Johnson, D.E. : Cystectomy for superflcial bladder cancer. Urology, 18, 459-463, 1981.

4) Cox, C.E., Case, A.S. and Boyce, W.H.: Bladder cancer: A 26-year review. J. Urol., 101, 550-558, 1969.

5) Goodwin, W.E. and Scardino, P.T. : Uretenosigmoidostomy. J. Urol., 118, 169-174, 1977.

6）浜野耕一郎，栃木宏水，森下文夫，堀内英輔，鈴木 紀元, 波部英夫, 加藤広海, 朴木繁博, 山崎義久, 斎藤 薫, 森 幸夫, 多田 茂: 膀胱腫湟の臨床的 観察. 泌尿紀要, 23，463-473，1977.

7) Hamlin, D.J. and Cockett, A.T.K.: Computed tomography of bladder: Staging of bladder cancer using low density opacification technique. Urology, 13, 331-334, 1979.

8）伊藤泰二, 森 義則, 永田 肇, 清原久和：膀胼腫 瘍270例の治療成績：TURを中心として。必泌紀 要, 22, 33-41, 1976.

9) Jewett, H.J., King, L.R. and Shelley, W.M.: A study of 356 cases of infiltrating bladder cancer: relation of certain pathological characteristics to prognosis after extirpation. J. Urol., 92, 668-678, 1964.

10）小松原秀一, 安藤 徹, 佐藤炤太郎: 膀胱腫場の治 療一15年間の臨床統計的観察から一: 西日泌尿, 
44, 31-39, 1972.

11) Mangi, J.: Partial cystectomy: A review of 104 cases. Brit. J. Urol., 34, 74-87, 1962.

12) Marshall, V.F., Holden, J. and Ma, K.T.: Survival of patients with bladder carcinoma treated by simple segmental resection. Cancer, 00, 568-571， 1956.

13）松浦 健, 杉山高秀, 辻橋宏典, 加藤良成, 朴 英 哲，国方聖司，神田英憲，片岡喜代徳，永井信夫， 金子茂男, 那健二郎, 井口正典, 秋山隆弘, 八竹 直, 栗田 孝: 膀胼腫瘍の臨床的検討. 泌尿紀要, 29, 23-30, 1983.

14）三方律治，木下健二, 阿部定則，柳沢良三，小松秀 樹, 本間之夫, 中村昌平: Universal gyroscopic X-ray IV apparatus 利用膀胼二重造影々経尿道 的超音波診断法. 日泌尿会誌, 73, 308-315, 1982.

15）三品輝男, 渡辺康介, 都田慶一, 荒木博孝, 藤原光 文, 渡辺 決：日泌尿会誌，68，678-685，1977。

16）村瀬達良, 藤田 潤, 垣添忠生, 松本想一, 岸紀代 三，下里幸雄：Mapping による膀胱癌の発育進展 形式に関する病理学的研究. 日泌尿会誌, 71, $829-839,1980$.

17）中村昌平：経尿道的超音波断層法の開発と膀胼 の臨床応用. 日泌尿会誌，72，511－529，1981.

18）日本泌尿器学会, 日本病理学会：泌尿器科・病理. 膀胼癌取扱い:規約. 第 1 版, 68-71, 金原出版, 東 京 11980.

19）新島端夫, 松村陽右, 片山泰購, 森永 修, 池 紀 征, 朝日俊彦, 尾崎雄治郎, 白石哲朗：膀胱腫湯の 臨床的統計的研究. 第 1 報. 治療法と予後を中心と して．日泌尿会誌，67，1057-1063，1976.

20）西尾恭規, 松本想一, 安藤 正, 垣添忠生：膀脱部 分切除術の検討一再発後, 膀脱全摘術を施行した 症例の治療成績一. 臨床泌尿器科, 36, 971-974, 1982.

21）沼里 進, 高橋崎三, 佐々木秀平, 伊藤幸夫, 小原 紀彰, 岩動 孝, 長根 裕, 吉田郁彦, 山田行夫, 村本俊一, 半田紘一, 久保 隆, 大堀 勉: 膀胀腫 瘍一治療と遠隔成績。泌尿紀要，18，345-352， 1972.

22) Richie, J.P., Skinner, D.G. and Kaufman, J.J. :
Radical custectomy for carcinoma of the bladder : 16 years of experience. J. Urol., 113, 186-189, 1975.

23）斉藤 清, 窪田吉信, 高井修道 : 膀胱腫瘍の保存的 治療後の再発について. 日泌尿会誌, 69, 373-380, 1978.

24) Schoenberg, H.W., Gregory, J.G. and Murphy, J. J. : Low mortality cystectomy in bladder cancer. J. Urol., 110, 671-674, 1973.

25) Soto, E.A., Friedell, G.H. and Tilman, A.J. : Bladder cancer as seen in giant histologic sections. Cancer, 39, 447-455, 1977.

26) Stone, J.H. and Hodges, C.V.: Radical cystectomy for invasive bladder cancer. J. Urol., 96, 207-209, 1966.

27）鈴木騏一, 杉田篤生, 三浦忠雄, 加藤正和, 小野寺 豊, 失吹日出雄, 加藤輝彦: 膀胱癌に対する膀胱部 分切除術の臨床的ならびに病理組織学的研究第 1 報膀胱部分切除術施行症例の臨床像たらびに遠隔 成績。日泌尿会誌，57，380-387，1966。

28）高安久雄, 小川秋実, 北川龍一, 柿沢至怒, 岸 洋 一, 赤座英之, 石田男 : 膀脂腫瘍の治療成績. 日 泌尿会誌, 69，669-678，1978。

29) Utz, D.C., Schmitz, S.E., Fugelso, P.D. and Farrow, G.M. : A clinicopathologic evaluation of partial cystectomy for carcinoma of the urinary bladder. Cancer, 32, 1075-1077, 1973.

30) Wajsman, Z., Merrin, C., Moore, R. and Murphy, G.P.: Current results from treatment of bladder tumors withtotal cy cystectomy at Roswell Park memorial institute. J. Urol., 113, 806-810, 1975.

31) Whitmore, W.F. Jr. and Marshall, V.F. : Radical total cystectomy for cancer of the bladder : 230 consecutive cases fibe years later. J. Urol., 87, 853-868, 1962.

32）吉田 修：膀胱癌に関する研究. 第 II 編. 膀脂癌 患者244例の臨庄的観察 (浸潤度および遠隔成績を 中心として). 泌尿紀要, 12, 1261-1280, 1966. (1983年 5 月 29 日受付) 